\title{
Progression of allergy and asthma through childhood to adolescence
}

\author{
Erika von Mutius
}

Asthma and wheezing are responsible for a significant proportion of acute and chronic illness in childhood. For example, in the United States in 1975, 28 million restricted activity days in children under 17 years of age were attributed to asthma. ${ }^{1}$

\section{Natural history of asthma}

Childhood asthma has long been thought of as a single, easily recognisable disease characterised by reversible (spontaneous or by treatment) airflow limitation. ${ }^{2}$ However, recent findings of an American population-based epidemiological survey have challenged this concept.

Martinez et $a l^{3}$ studied the natural history of wheezing in children aged 0-6 years and found that approximately half of the children experienced wheezing illness at some time during the study period. In some of them wheezing occurred early in life but resolved by the age of three years (transient early wheezing), some experienced wheezing illness between the ages of three and six years (late onset wheezing), and others had wheezing illness throughout the entire study period (persistent wheezing).

Different risk factors were associated with these outcomes. The children with transient early wheezing had reduced pulmonary function, as measured by functional residual capacity (VmaxFRC) shortly after birth and before any lower respiratory tract illness had occurred. The risk of transient early wheezing was also increased in the children of mothers who smoked during pregnancy; these children had significantly lower Vmax FRC values than children of non-smoking women. Congenitally smaller airways may therefore predispose children to wheezing illness early in life.

Children with persistent and late onset wheezing were more likely than non-wheezing or transient early wheezing children to be atopic (assessed by serum IgE levels and skin test reactivity) and to have asthmatic mothers. Moreover, pulmonary function in the persistent wheezers, which was within normal limits in the first year of life, had decreased by the age of six years, thus indicating more severe disease or the long term consequences of recurrent airway obstruction. The study suggests the

\section{University Children's Hospital, Munich, Germany Erika von Mutius}

Very little is known about the progression of asthma through childhood and adolescence. Clinical studies have reported that up to $80 \%$ of asthmatics become asymptomatic during puberty. ${ }^{45}$ In a cohort study of Australian schoolchildren $^{6}$ tested initially at the age of $8-10$ years and then again at $12-14$ years of age, the persistence of bronchial hyperresponsiveness at 12-14 years of age was found to be related to the severity of disease at $8-10$ years of age, the atopic status of the child, and the occurrence of asthma in the parents. Most of the children who had a slight or mild degree of bronchial hyperresponsiveness at 8-10 years of age lost their increased response by the age of $12-14$ years. However, only $15 \cdot 4 \%$ of children with severe or moderate bronchial hyperresponsiveness at the initial assessment had normal levels of bronchial responsiveness at the later assessment. Whether the decline in reported symptoms is real or the result of the children increasingly denying their illness as they reach puberty remains to be clarified. The reduction in bronchial hyperresponsiveness may favour the hypothesis of a real reduction in the activity of the disease. Alternatively, higher doses of histamine or methacholine may be needed to provoke hyperresponsiveness in larger airways of rapidly growing children.

... the occurrence of asthma within families is the strongest risk factor for the development of asthma in children.

What factors induce childhood asthma? In most studies the occurrence of asthma within families is the strongest risk factor for the development of asthma in children. ${ }^{7-10}$ However, asthma is a complex disorder in which genetic studies have proved to be challenging.

\section{ATOPY}

In children, as in adults, the prevalence of asthma and bronchial hyperresponsiveness is strongly related to serum IgE levels and skin test reactivity. ${ }^{11-13}$ Almost no asthma and bronchial hyperresponsiveness is present in subjects with the lowest IgE levels. However, the relative risks of different atopic sensitivities for the development of asthma and bronchial hyperresponsiveness have not been established conclusively.

Peat et $a l^{14}$ investigated the relationship between atopy, asthma, and bronchial hyperresponsiveness in three populations of children presence of two distinct phenotypes of wheezing illness - transient early and persistent wheezing - but no single disease entity up to the age of six years. 
living in different climatic areas of Australia. Each study region was characterised by different exposure levels to house dust mites and moulds. The association between sensitivity to specific allergens, bronchial hyperresponsiveness, and asthma differed in each region and was strongest for the most prevalent allergen in each study area. These results indicate that the level of allergen exposure may determine the type of sensitivity in a given population. To what extent and mechanism genes controlling the regulation of total and specific IgE production transfer the susceptibility for asthma remains to be elucidated. ${ }^{1516}$ Moreover, a specific hereditary factor not related to atopy or bronchial hyperresponsiveness may also determine the expression of asthma in children. ${ }^{17}$

\section{PREMATURITY}

Several studies have reported an increased prevalence of respiratory symptoms, such as cough and wheeze, and reductions in lung function in children and adolescents who were born prematurely or who were of low birth weight. ${ }^{18-20}$ We have previously shown that girls who were born prematurely were diagnosed asthmatic significantly more often and had significantly more respiratory symptoms, such as recurrent wheezing, shortness of breath, and frequent cough with exercise, than full term girls, especially if they had required mechanical ventilation after birth. ${ }^{21}$ Significant reductions were also demonstrated in other parameters of lung function in these children.

However, no difference was found in atopic sensitivity between premature and full term children. Wheeze and cough in premature children may therefore be attributable to persistent anatomical abnormalities of the airways or parenchyma due to a reduction in lung function at birth, neonatal lung injury, and the increased risk of developing lower respiratory tract illnesses in infancy, rather than to an increased prevalence of atopy. Persistent wheeze in children who were born prematurely or who were of low birth weight may therefore represent a distinct wheezing phenotype which should not be confused with childhood asthma.

\section{DIET}

As societies become more affluent their dietary habits change, and such changes have been linked with the increased prevalence of asthma observed in recent years. ${ }^{22-24}$ Prospective studies have found that breast feeding has a transient beneficial effect on the incidence of eczema, food allergy, atopic sensitisation, and wheezing illnesses in the first three years of life. ${ }^{2526}$ Breast feeding may also prevent infectious diseases of the respiratory and gastrointestinal tracts. ${ }^{27}$ However, there is little evidence for a persistent protective effect of breast feeding on the incidence of childhood asthma. ${ }^{2829}$

A result of an increased awareness of the potential adverse effects of fats on the heart and the balance of unsaturated and saturated fats in the diet may have altered in favour of polyunsaturated oils. A recent Australian study ${ }^{30}$ showed a lower prevalence of asthma and bronchial hyperresponsiveness in children with a high intake of fresh oily fish. In addition, the results of a previous study ${ }^{31}$ indicated an association between high fish consumption and improved baseline levels of forced expiratory volume in one second $\left(\mathrm{FEV}_{1}\right)$ in the USA. Children who eat fish regularly consume more omega- 3 fatty acids which may protect them from bronchial hyperresponsiveness. However, a recent study found that although dietary supplementation with fish oil did increase levels of plasma neutrophils, no concomitant decrease in symptom scores or bronchial hyperresponsiveness in pollen sensitive subjects was observed. Finally, the severity of asthma - not its inception - has also been linked to increased salt intake, but only in males. ${ }^{32}$

\section{AIR POLLUTION}

Air pollution has repeatedly been cited as a causal factor in the development of asthma, and the effects of exposure to tobacco smoke in particular have been extensively investigated. A summary of the literature on the adverse effects of tobacco smoke produced by the US Environmental Protection Agency ${ }^{33}$ concludes that passive exposure to tobacco smoke is causally associated with the following:

1. An increased risk of lower respiratory tract infections, such as bronchitis and pneumonia, in infants and young children.

2. A small but significant dose-dependent reduction in pulmonary function.

3. Additional episodes and increased severity of asthma symptoms in asthmatic children.

Exposure to tobacco smoke is also considered to be a risk factor for the development of new cases of asthma in children. Furthermore, in the longitudinal Tucson Children's Respiratory Study, maternal smoking was related to both transient early wheezing and persistent wheezing. ${ }^{3}$

There is no evidence to support the hypothesis that high levels of sulphur dioxide and particulate matter cause asthma and allergy. In areas of East Germany and Poland, where the concentrations of sulphur dioxide and particulate matter are high, the prevalence of asthma, bronchial hyperresponsiveness, and atopic sensitivity were significantly lower than in less polluted areas in West Germany and Sweden. ${ }^{34-36}$ However, the increasing prevalence of bronchitis and symptoms of the upper respiratory tract may be associated with increasing levels of these pollutants. ${ }^{3437}$

Very little is known about the effects of exposure to traffic pollution on health. An increase in the prevalence of non-specific respiratory symptoms and reductions in lung function have been shown in children living in Munich school districts with heavy traffic. ${ }^{38}$ These changes were of similar type and magnitude to those seen when children are exposed passively to tobacco smoke. Ishizaki et $a l^{39}$ reported a strong association between allergic rhinitis to cedar pollen and exhaust fumes, 
though other factors were not taken into account. Other investigators have failed to show a relationship between exposure to traffic pollution and the prevalence of hay fever or asthma. ${ }^{3840}$ It remains to be seen if the results of animal experiments, which indicate an enhanced atopic sensitivity to ovalbumin in guinea pigs and mice exposed to traffic-related pollutants, can be applied to man. ${ }^{4142}$

The effects of ozone on the pulmonary function and respiratory symptoms of both healthy and asthmatic individuals have mainly been investigated in exposure chamber studies. The magnitude of the spirometric changes and the occurrence of respiratory symptoms, such as cough, shortness of breath, and pain on deep inspiration, attributable to a specified level of exposure have been shown to vary widely among individuals. ${ }^{434}$ The alterations of lung function and the prevalence of symptoms are reported to be highly reproducible, ${ }^{4546}$ reflecting an individual's intrinsic response to ozone. However, rapid adaptation to continuing exposure has also been observed by most investigators. ${ }^{47-49}$ Increases in bronchial responsiveness to histamine and methacholine in healthy subjects following exposure to ozone have been demonstrated, but it is unknown whether these changes persist following exposure. ${ }^{49}$ Very few epidemiological studies have investigated the effects of long term exposure to ozone on the prevalence of asthma and atopic diseases, and the results of the available studies are conflicting. ${ }^{5051}$ At present, therefore, little evidence exists to support a causal role of ozone in the inception of reactive airway disease or atopy.

\section{OTHER FACTORS}

The different lifestyles in Eastern and Western societies may account for the two- to threefold difference in the prevalence of skin test reactivity between these regions. Strachan first demonstrated that the prevalence of hayfever was inversely correlated to the number of siblings. ${ }^{52}$ As the effect was much stronger for older than for younger siblings, he suggested that exposure to infectious diseases early in life may have a protective effect on the development of atopic diseases. This hypothesis may be applied to the situation in East and West Germany since in East Germany most of the children attended daycare nurseries from their first birthday onwards, whereas in West Germany daycare is accessible only to a minority of children in this age group. ${ }^{35}$

Lifestyle factors, such as decreasing family size, exposure to viral infections early in life, and socioeconomic status, may be of greater importance for the development of atopic sensitivity than exposure to ambient high concentrations of sulphur dioxide and particulate matter.

\section{What factors suppress childhood asthma?}

Exposure to indoor allergens, particularly house dust mites and cats, has been related to the presence and severity of childhood asthma. Allergen avoidance - for example, by hospital admission, ${ }^{53}$ residence at high altitude, ${ }^{54}$ or mattress encasement ${ }^{55}$ - has consistently been shown to reduce both symptoms and bronchial hyperresponsiveness in asthmatic patients. However, whether indoor allergen avoidance can prevent atopic sensitisation and the development of childhood asthma in genetically predisposed or otherwise susceptible individuals is unclear.

Concentrations of $2 \mu \mathrm{g} / \mathrm{g}$ dust of $\operatorname{Der} p \mathrm{I}$, the major house dust mite allergen, and $8 \mu \mathrm{g} / \mathrm{g}$ dust of $\mathrm{Fel} d \cdot \mathrm{I}$, the major cat allergen, have been proposed as threshold levels for increasing the risk of sensitisation. However, it may be difficult to achieve a sufficient reduction in allergen levels in ambient dust and air as significant amounts of allergen are found in public buildings or, in the case of Fel $d \mathrm{I}$, in homes without cats. ${ }^{56}$ Moreover, lack of sensitivity to indoor allergens may not prevent sensitisation to, for example, moulds, which have been shown to be strongly related to asthma in arid regions. ${ }^{14}$

The reduction in asthma symptoms and bronchial hyperresponsiveness in adolescence is not well understood.

\section{Summary}

The reduction in asthma symptoms and bronchial hyperresponsiveness in adolescence is not well understood. Nor can the differences in asthma prevalence and severity between the sexes, which reverse at puberty, be explained. It has been suggested that the improvement in asthma during adolescence may result from diminished clinical and immunological responsiveness directly related to hormonal changes $^{57}$ and that the effect of age on the prevalence of asthma in each sex may relate to differences in hormonal status, potentially influencing airway size, inflammation, and smooth muscle and vascular functions. ${ }^{58}$ However, few comprehensive studies are available.

In summary, all wheezing is not asthma. Non-asthmatic wheezing illnesses may in part be attributable to anatomical abnormalities of the lung (transient early wheezing, premature birth). Little is known about the genetic and environmental determinants of childhood asthma, and factors related to the development of atopic sensitisation, such as exposure to allergens, infectious diseases, or tobacco smoke early in life, and dietary habits may be important, whereas the relevance of air pollution remains to be established. Unfortunately, we still do not know how to prevent the manifestation of childhood asthma.

1 National Center for Health Statistics. Asthma: United States, 1980-1987. MMWR 1990;39:493-97.

2 Murphy S. Asthma: an inflammatory disease. In: Hilman BC, ed. Pediatric respiratory disease. Diagnosis and treatment.

3 Martinez FD, Wright AL, Taussig LM, Holberg CJ, Halonen M, Morgan WJ, et al. Asthma and wheezing in the first six years of life. $N$ Engl $\mathcal{F}$ Med 1995;332:133-8. 4 Park ES, Golding J, Carswell F, Stewart-Brown S. Pre- 
school wheezing and prognosis at 10 . Arch Dis Child 1986 61:642-6.

5 Balfour-Lynn. Childhood asthma and puberty. Arch Dis Child 1985;60:231-5.

6 Peat JK, Salome CM, Sedgwick CS, Kerrebijn J, Woolcock AJ. A prospective study of bronchial hyperresponsiveness and respiratory symptoms in a population of Australia schoolchildren. Clin Exp Allergy 1989;19:299-306.

7 Ownby DR. Environmental factors versus genetic determinants of childhood inhalant allergies. $\mathcal{f}$ Allengy Clin Immunol 1990;86:279-87.

8 Frischer T, Kuehr J, Meinert R, Karmaus W, Urbanek R Risk factors for childhood asthma and recurrent wheezy bronchitis. Eur $\mathcal{f}$ Pediatr 1993;152:771-5.

9 Sherman CB, Tosteson TD, Tager IB, Speizer FE, Weis ST. Early childhood predictors of asthma. Am $\mathcal{F}$ Epidemio 1990;132:83-95.

10 Sibbald B, Horn MEC, Gregg I. A family study of the genetic basis of asthma and wheezy bronchitis. Arch Dis Child 1980;55:354-7.

11 Burrows B, Martinez FD, Halonen M, Barbee RA, Cline MG. Association of asthma with serum IgE levels and skin-test reactivity to allergens. $N$ Engl f Med 1989;320: 271-7.

12 Sears MR, Burrows B, Flannery EM, Herbison GP, Hewit CJ, Holdaway MD. Relation between airway responsiveness and serum IgE in children with asthma and in apparently normal children. $N$ Engl f Med 1991;325: 1067-71.

13 Zimmerman B, Feanny S, Reisman J, Hak H, Rashed N, McLaughlin FJ, et al. Allergy in asthma. $f$ Allergy Clin Immunol 1988;81:63-70.

14 Peat JK, Woolcock AJ. Sensitivity to common allergens: relation to respiratory symptoms and bronchial hyperresponsiveness in children from three different climatic areas of Australia. Clin Exp Allergy 1991;21:573-81.

15 Marsh DG, Neely JD, Breazeale DR, Ghosh B, Freidhoff LR, Ehrlich-Kautzky E, et al. Linkage analysis of ILA and other chromosome $5 \mathrm{q} 31.1$ markers and total serum immunoglobulin E concentrations. Science 1994;264: 1152-6.

16 Cookson WOCM, Young RP, Sandford AJ, Moffat MF Shirakawa T, Sharp PA, et al. Maternal inheritance of atopic IgE responsiveness on chromosome 11q. Lancet 1992;340:381-4.

17 von Mutius E, Nicolai T. Familial aggregation of asthma in a South Bavarian population. Am $\mathcal{\exists}$ Respir Crit Car Med 1995 (in press).

18 Chan KN, Elliman A, Bryan E, Silverman M. Respiratory symptoms in children of low birth weight. Arch Dis Child 1989;64:1294-304.

19 Chan KN, Noble-Jamieson CM, Elliman A, Bryan EM Silverman M. Lung function in children of low birth weight. Arch Dis Child 1989;64:1284-93.

20 Mansell AL, Driscoll JM, James LS. Pulmonary follow-up of moderately low birth weight infants with and withou respiratory distress syndrome. 7 Pediatr 1987;110:111-5.

21 von Mutius E, Nicolai T, Martinez FD. Prematurity as a risk factor for asthma in preadolescent children. $\mathcal{F}$ Pediat 1993:123:223-9.

22 Robertson CF, Heycock E, Bishop J, Nolan T, Olinsky A Phelan PD. Prevalence of asthma in Melbourne schoolchildren: changes over 26 years. $B M F$ 1991;302:1116-8.

23 Ninan T, Russell G. Respiratory symptoms and atopy in Aberdeen schoolchildren: evidence from two surveys 25 years apart. $B M \mathcal{F} 1992 ; 304: 873-5$.

24 Peat JK, van den Berg RH, Green WF, Mellis CM, Leeder SR, Woolcock AJ. Changing prevalence of asthma in Australian children. $B M \mathcal{F} 1994 ; 308: 1591-6$.

25 Chandra RK. Prospective studies of the effect of breast feeding on incidence of infection and allergy. Acta Paediatr Scand 1979;68:691-4.

26 Fergusson DM, Horwood JL, Shannon FT, Taylor B. Breas feeding, gastrointestinal and lower respiratory illness in the first two years. Aust Paediatr f 1981;17:191-5.

27 Wright AL, Holberg CJ, Martinez FD, Morgan WJ, Taussig LM, GHMA. Breast feeding and lower respiratory tract illness in the first year of life. BMF 1989;299:946-9.

28 Burr ML, Limb ES, Maguire MJ, Amarah L, Eldridge BA Layzell JCM, et al. Infant feeding, wheezing, and allergy: a prospective study. Arch Dis Child 1993;68:724-8.

29 Poysa L, Korppi M, Remes K, Juntunen-Backman K. Atopy in childhood and diet in infancy. A nine-year follow-up study. I. Clinical manifestations. Allergy Proc 1991;12. 107-11.

30 Peat JK, Hodge L, Salome CM, Woolcock AJ. Dietary fish intake and asthma in children. Am F Respir Crit Care Med 1995;151(Suppl):A469.

31 Schwartz J, Weiss ST. The relationship of dietary fish intake to level of pulmonary function in the first National Healt and Nutrition Survey (NHANES I). Eur Respir $\mathcal{F}$ 1994;7: $1821-4$

32 Carey OJ, Locke C, Cookson JB. Effect of alterations of dietary sodium on the severity of asthma in men. Thorax 1993;48:714-8.
33 National Research Council. Environmental tobacco smoke: measuring exposures and assessing health effects. Washington, USA: National Academy Press, 1986.

34 von Mutius E, Fritzsch C, Weiland SK, Roell G, Magnussen $\mathrm{H}$. Prevalence of asthma and allergic disorders among children in united Germany: a descriptive comparison. BMF 1992;305:1395-9.

35 von Mutius E, Martinez FD, Fritzsch C, Nicolai T, Roel G, Thiemann HH. Prevalence of asthma and atopy in two areas of West and East Germany. Am $\mathcal{F}$ Respir Crit Care Med 1994;149:358-64.

36 Braback L, Breborowicz A, Dreborg S, Knutsson A, Pieklik $\mathrm{H}$, Bjorksten B. Atopic sensitization and respiratory symptoms among Polish and Swedish school children. Clin Exp Allergy 1994;24:826-35.

37 von Mutius E, Sherrill DL, Fritzsch C, Martinez FD, Lebowitz MD. Air pollution and upper respiratory symptoms in children from East Germany. Eur Respir $\mathcal{F} 1995$ 8:723-8.

38 Wjst $M$, Reitmeir P, Dold S, Wulff A, Nicolai T, von Loeffelholz-Colberg E, et al. Road traffic and adverse effects on respiratory health in children. BMf 1993;307: 596-600.

39 Ishizaki T, Koizumi K, Ikemori R, Ishyama Y, Kushibiki E. Studies of prevalence of Japanese cedar pollinosis among the residents in a densely cultivated area. Ann Allergy 1987;58:265-70.

40 Waldron G, Pottle B, Dod J. Asthma and the motorways one district's experience. $\mathcal{F}$ Publ Health Med 1995;17:85-9.

41 Muranaka M, Suzuki S, Koizumi K, Takafuji S, Miyamoto T, Ikemori R, et al. Adjuvant activity of diesel-exhaus particulates for the production of IgE antibody in mice. $千$ Allergy Clin Immunol 1986;77:616-23.

42 Riedel F, Krämer M, Scheibenbogen C, Rieger CHL. Effects of $\mathrm{SO}_{2}$ exposure on allergic sensitization in the guinea pig. of $\mathrm{S}_{2}$ exposure on allergic sensitization
$f$ Allergy Clin Immunol 1988;82:527-34.

43 Folinsbee LJ, Bedi JF, Horvath SM. Respiratory responses in humans repeatedly exposed to low concentrations of ozone. Am Rev Respir Dis 1980;121:431-9.

44 Weinmann GG, Bowes SM, Gerbase MW, Kimball AW, Frank R. Response to acute ozone exposure in healthy men. Results of a screening procedure. Am $\mathcal{F}$ Respir Crit Care Med 1995;151:33-40.

45 McDonnell III WF, Chapman RS, Leigh MW, Strope GL, Collier AM. Respiratory responses of vigorously exercising children to $0 \cdot 12 \mathrm{ppm}$ ozone exposure. Am Rev Respir Dis 1985;132:875-9.

46 McDonnell III WF, Hortsman DH, Abdul-Salaam S, House DE. Reproducibility of individual responses to ozone exposure. Am Rev Respir Dis 1985;131:36-40

47 Farrel BP, Kerr HD, Kulle TJ, Sauder LR, Young JL Adaptation in human subjects to the effects of inhaled ozone after repeated exposure. Am Rev Respir Dis 1979 119:725-30

48 Folinsbee LJ, Bedi JF, Horvath SM. Respiratory responses in humans repeatedly exposed to low concentrations of ozone. Am Rev Respir Dis 1980;121:431-9.

49 Folinsbee IJ, Hortsman DH, Kehrl HR, Harder S, AbdulSalaam S, Ives PJ. Respiratory responses to repeated prolonged exposure to $0 \cdot 12 \mathrm{ppm}$ ozone. Am $\mathfrak{f}$ Respir Crit Care Med 1994;149:98-105.

50 Dockery DW, Speizer FE, Stram DO, Ware JH, Spengler JD, Ferris BG Jr. Effects of inhalable particles on respiratory health of children. Am Rev Respir Dis 1989;139: 587-94.

51 Stern BR, Raizenne ME, Burnett RT, Jones L, Kearney J, Franklin CA. Air pollution and childhood respiratory health: exposure to sulfate and ozone in 10 Canadian rural communities. Environ Res 1994;66:125-42.

52 Strachan DP. Hay fever, hygiene, and household size. $B M^{f}$ 1989;299:1259-60.

53 Platts-Mills TAE, Tovey ER, Mitchell EB, Moszoro $\mathrm{H}$ Nock P, Wilkins SR. Reduction of bronchial hyperreactivity during prolonged allergen avoidance. Lance 1982;ii:675-7.

54 Charpin D, Birnbaum J, Haddi E, Genard G, Lanteaum $\mathrm{A}$, Toumi $\mathrm{M}$, et al. Altitude and allergy to house-dust mites. A paradigm of the influence of environmental exposure on allergic sensitization. Am Rev Respir Dis 1991;143:983-6.

55 Ehnert B, Lau-Schadendorf S, Weber A, Buettner P, Schou C, Wahn U. Reducing domestic exposure to dust mite allergen reduces bronchial hyperreactivity in sensitive children with asthma. $₹$ Allergy Clin Immunol 1992;90:135-8.

dren with asthma. I Allergy Clin Immunol 1992;90:135-8.
56 Munir AK, Einarsson R, Schou C, Dreborg SK. Allergen Munir AK, Einarsson R, Schou C, Dreborg SK. Allergens
in school dust. I. The amount of the major cat (Fel $d \mathrm{I}$ ) in school dust. I. The amount of the major cat (Fel $d$ I) is high enough to probably cause perennial symptoms in is high enough to probably cause perennial symptoms in most children with asthma who are sensitized

57 Hill DJ, Hosking CS, Shelton MJ, Turner MW. Growing out of asthma: clinical and immunological changes ove 5 years. Lancet 1981;ii:1359-62.

58 Redline S, Gold D. Challenges in interpreting gender differences in asthma. Am $\mathcal{J}$ Respir Crit Care Med 1994 150:1219-21. 